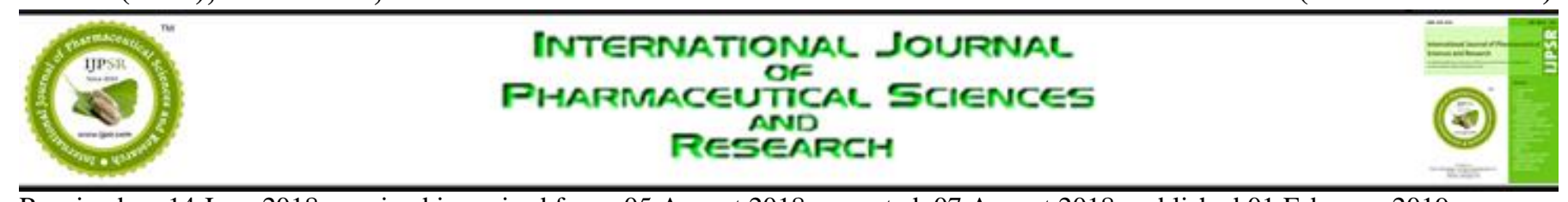

Received on 14 June 2018; received in revised form, 05 August 2018; accepted, 07 August 2018; published 01 February 2019

\title{
PREFORMULATION STUDY OF PIROXICAM
}

Ashwini A. Bachhav ${ }^{*}{ }^{1}$, Satish A. Ahire ${ }^{2}$ and Anil G. Jadhav ${ }^{1}$

Department of Pharmaceutics 1, Sandip Institute of Pharmaceutical Sciences, Nashik - 422213, Maharashtra, India.

Art, Science and Commerce College ${ }^{2}$, Surgana, Nashik - 422211, Maharashtra, India.

Keywords:

Preformulation, Piroxicam, Dosage form, Characterization

Correspondence to Author:

Ashwini A. Bachhav

Assistant Professor,

Department of Pharmaceutics,

Sandip Institute of Pharmaceutical

Sciences, Nashik - 422213,

Maharashtra, India.

E-mail: ashwini27212@gmail.com

\begin{abstract}
Preformulation testing is the first step in the rational development of dosage forms of a drug substance. The preformulation investigations confirm that there are no significant barriers to the compound's development as a marketed drug. The formulation scientist uses this information to develop an efficacious, stable and safe dosage form. The main objective of the present research work was to do preformulation study of piroxicam drug. Piroxicam (PC) is one of the most potent non-steroidal anti-inflammatory agents that also has anti-pyretic activity and has been used for the treatment of rheumatoid arthritis, osteoarthritis, ankylosing spondylitis, tendinitis, bursitis, and for the pain that is not related to a musculoskeletal system and traumatic contusions. The Principal advantage of piroxicam is its long half-life, which permits the administration of a single daily dose. As the piroxicam is very effective drug, many researchers use this drug in their research. This research paper helps those people who want to use piroxicam drug for their research.
\end{abstract}

INTRODUCTION: Preformulation testing is the first step in the rational development of dosage forms of a drug substance. The preformulation study is the process of optimizing the delivery of the drug through the determination of physicochemical properties of the new compound that could affect drug performance and development of an efficacious, stable and safe dosage form. It gives the information needed to define the nature of the drug substance and provide a framework for the drug combination with pharmaceutical excipients in the dosage form.

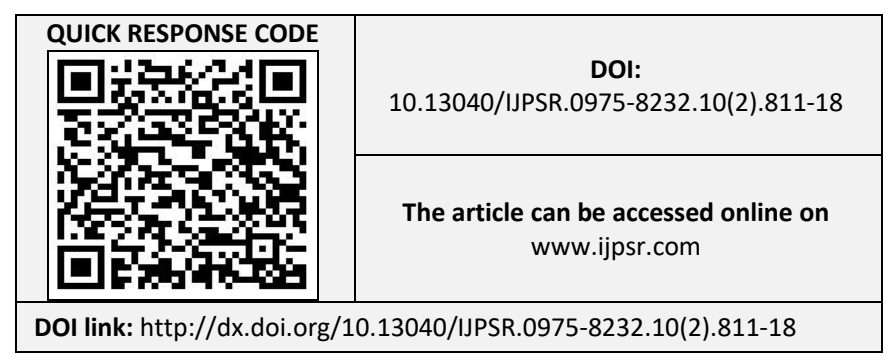

Hence, Preformulation studies were performed for the obtained sample of the drug for identification and compatibility studies. Preformulation may be described as a phase of the research and development process where the preformulation scientist characterizes the physical, chemical and mechanical properties of a new drug substance, to develop stable, safe and effective dosage form. The preformulation investigations confirm that there are no significant barriers to the compound's development as a marketed drug. The formulation scientist uses this information to develop dosage forms. Preformulation is a multidisciplinary development of a drug candidate.

\section{Principal Areas of Preformulation: Bulk Characterization:}

i. Crystallinity and polymorphism

ii. Hygroscopicity 
iii. Fine particle characterization.

iv. Powder flow.

\section{Solubility Analysis:}

i. Ionization constant $-\mathrm{pKa}$.

ii. $\mathrm{pH}$ solubility profile.

iii. Common ion effect $-K_{S P}$.

iv. Thermal effects.

v. Solubilization

vi. Partition coefficient.

vii. Dissolution

\section{Stability Analysis:}

i. Stability in toxicology formulation.

ii. Solution stability- $\mathrm{pH}$ stability profile.

iii. Solid state stability - Bulk stability, Compatibility.

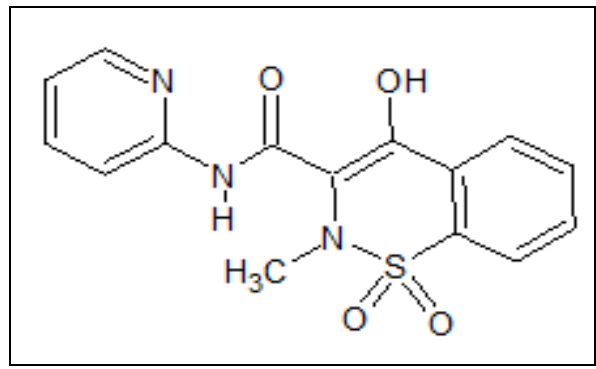

FIG. 1: PIROXICAM

Piroxicam is an oxicam derivative medication belonging to non steroidal anti-inflammatory drugs (NSAIDs) group, used to treat moderate to severe inflammatory diseases such as rheumatoid arthritis, osteoarthritis, ankylosing spondylitis (Bechterew's disease), tendinitis, bursitis, and for pain that is not related to musculoskeletal system e.g. primary dysmenorrhea and postoperative pain. It reduces pain, joint swelling, morning stiffness, and improves the functionality of the joints during chronic polyarthritis ${ }^{2}$.

PC has been classified in the biopharmaceutics Drug Classification system as a Class II drug with low solubility and high permeability. It demonstrates a slow and gradual absorption via the oral route and has a long half-life of elimination, rendering a prolonged therapeutic action and a delayed onset of anti-inflammatory and analgesic effect ${ }^{3}$ PC is well absorbed following oral administration; however, its use has been limited by a number of side effects, including bleeding and ulceration.
Although as piroxicam have different side effects but, its pharmacological action is more as piroxicam is an effective anti-inflammatory agent; it is an inhibitor of prostaglandin biosynthesis. The Principal advantage of piroxicam is its long halflife, which permits the administration of a single daily dose. Piroxicam is approved in the United States for the treatment of rheumatoid arthritis and osteoarthritis. It also has been used in the treatment of ankylosing spondylitis, acute musculoskeletal disorders, dysmenorrhea, postoperative pain and acute gout ${ }^{4}$. This paper helps to those people who want to use piroxicam drug for their research. As the piroxicam is very effective drug many researchers use this drug some of the research paper is listed below:

1. Formulation and optimization of piroxicam orodispersible tablets by central composite design ${ }^{4}$.

2. Development of proniosomal drug delivery with a different type of penetration enhancers ${ }^{5}$.

3. Characterization and in-vitro evaluation of piroxicam suppositories ${ }^{6}$.

4. Novel double loaded transferosomes: evidence of superior anti-inflammatory efficacy- a comparative study ${ }^{7}$.

5. Design and evaluation of piroxicam microemulsion ${ }^{8}$.

6. Pharmaceutical cocrystal of piroxicam: design, formulation, and evaluation ${ }^{9}$.

7. Formulation and characterization of flexible phosphatidylcholine vesicles for systemic delivery of piroxicam ${ }^{10}$.

8. Systematic development of transethosomal gel system of piroxicam: formulation optimization, in-vitro evaluation and ex-vivo assessment ${ }^{11}$.

9. Development and validation of a sensitive UV method for piroxicam: application for skin permeation studies ${ }^{12}$.

\section{EXPERIMENTAL WORK:}

Organoleptic Properties: The drug samples were studied for appearance, color, and odor. The results are shown in Table 1.

Melting Point: The melting points of the drugs were determined by an open capillary method using the melting point apparatus. The melting point is shown in Table 2. 
Ultraviolet Spectroscopy: ${ }^{13,14}$ Determination of Maximum Wavelength $\left(\lambda_{\max }\right)$ : a. In Methanol: Drug (10 mg) was accurately weighed and transferred to $100 \mathrm{ml}$ volumetric flask, volume was made up to the mark with methanol to obtain strength $100 \mu \mathrm{g} / \mathrm{ml}$. It was used as a standard stock solution. This stock solution was further diluted suitably to give a concentration of $10 \mu \mathrm{g} / \mathrm{ml}$. The UV spectrums were recorded in the range $200-400 \mathrm{~nm}$ by using UV-Visible double beam spectrophotometer (Shimadzu 2450). The wavelength of maximum absorption $\left(\lambda_{\max }\right)$ was determined and is shown in Fig. 2 and Table 3.

b. In methanolic HCl: ${ }^{15}$ Drug (10 mg) was accurately weighed and transferred to $100 \mathrm{ml}$ volumetric flask, volume was made up to the mark with $0.1 \mathrm{M}$ methanolic $\mathrm{HCl}$ to obtain strength 100 $\mu \mathrm{g} / \mathrm{ml}$. It was used as a standard stock solution. This stock solution was further diluted suitably to give a concentration of $10 \mu \mathrm{g} / \mathrm{ml}$. The UV spectrums were recorded in the range 200-400 nm by using UV-Visible double beam spectrophotometer (Shimadzu 2450). The wavelength of maximum absorption $\left(\lambda_{\max }\right)$ was determined and is shown in Fig. 3 and Table 3.

c. In Phosphate Buffer (pH-7.4): $20 \mathrm{mg}$ of drug was accurately weighed, transferred into a $100 \mathrm{ml}$ volumetric flask and dissolved in $15 \mathrm{ml}$ of methanol. The volume was made up to $100 \mathrm{ml}$ using PBS pH 7.4 to get a concentration of 200 $\mu \mathrm{g} / \mathrm{ml}$. From the prepared stock solution, $10 \mathrm{ml}$ solution was withdrawn and transferred to another $100 \mathrm{ml}$ volumetric flask and volume were makeup to $100 \mathrm{ml}$ to get a concentration of $20 \mu \mathrm{g} / \mathrm{ml}$. The UV spectrums were recorded in the range 200-400 $\mathrm{nm}$ by using UV-Visible double beam spectrophotometer (Shimadzu 2450). The wavelength of maximum absorption $(\lambda \max )$ was determined and is shown in Fig. 4 and Table 3.

\section{Determination of Beer-Lambert's Plot:}

a. In Phosphate Buffer (pH-7.4): $20 \mathrm{mg}$ of drug was accurately weighed, transferred into a $100 \mathrm{ml}$ volumetric flask and dissolved in $15 \mathrm{ml}$ of methanol. The volume was made up to $100 \mathrm{ml}$ using PBS pH 7.4to get a concentration of 200 $\mu \mathrm{g} / \mathrm{ml}$. From the prepared stock solution, $10 \mathrm{ml}$ solution was withdrawn and transferred to another $100 \mathrm{ml}$ volumetric flask and volume was makeup to
$100 \mathrm{ml}$ to get a concentration of $20 \mu \mathrm{g} / \mathrm{ml}$. From the above solution 1, 2, 3, 4, and $5 \mathrm{ml}$ of solutions were separately transferred into $10 \mathrm{ml}$ volumetric flasks respectively, and volume was made up to 10 $\mathrm{ml}$ to get a concentration of $2,4,6,8,10 \mu \mathrm{g} / \mathrm{ml}$ respectively. To scan the wavelength maxima 20 $\mu \mathrm{g} / \mathrm{ml}$ solution was taken in a quartz cuvette and scanned on UV-Visible double beam spectrophotometer in range of $200-400 \mathrm{~nm}$. The aboveprepared samples were analyzed at $354 \mathrm{~nm}\left(\lambda_{\max }\right)$. Calibration Curve is shown in Fig. 5.

b. In methanolic HCl: ${ }^{15} 10 \mathrm{ml}$ of $100 \mu \mathrm{g} / \mathrm{ml}$ standard stock solution was diluted up to $50 \mathrm{ml}$ to obtain a standard working solution of $20 \mu \mathrm{g} / \mathrm{ml}$ concentration which was used for further dilutions of the calibration curve. Aliquots $(2.5,3.7,5.0,6.2$, 7.5) $\mathrm{ml}$ of $20 \mu \mathrm{g} / \mathrm{ml}$ working standard solution corresponding to $2.5-7.5 \mu \mathrm{g} / \mathrm{ml}$ were taken in a series of $20 \mathrm{ml}$ volumetric flask and volume made up with $0.1 \mathrm{M}$ methanolic $\mathrm{HCl}$. The absorbance measurements of these solutions were carried out against $0.1 \mathrm{M}$ methanolic $\mathrm{HCl}$ as blank at $334.5 \mathrm{~nm}$. A calibration curve was plotted in Fig. 6.

c. In Methanol: $20 \mathrm{mg}$ of drug was accurately weighed, transferred into $100 \mathrm{ml}$ volumetric flask and dissolved in $15 \mathrm{ml}$ of methanol. The volume was made up to $100 \mathrm{ml}$ using methanol get a concentration of $200 \mu \mathrm{g} / \mathrm{ml}$. From the prepared stock solution, $10 \mathrm{ml}$ solution was withdrawn and transferred to another $100 \mathrm{ml}$ volumetric flask and volume was makeup to $100 \mathrm{ml}$ to get a concentration of $20 \mu \mathrm{g} / \mathrm{ml}$.

From the above solution 1, 2, 3, 4, and $5 \mathrm{ml}$ of solutions were separately transferred into $10 \mathrm{ml}$ volumetric flasks respectively, and volume was made up to $10 \mathrm{ml}$ to get a concentration of $2,4,6$, $8,10 \mu \mathrm{g} / \mathrm{ml}$ respectively. To scan the wavelength maxima $20 \mu \mathrm{g} / \mathrm{ml}$ solution was taken in a quartz cuvette and scanned on UV-Visible double beam spectrophotometer in range of 200-400 $\mathrm{nm}$. The above-prepared samples were analyzed at $333 \mathrm{~nm}$ $\left(\lambda_{\max }\right)$. Calibration Curve is shown in Fig. 7.

Solubility Study of Drug: ${ }^{15}$ Solubility studies of the drug were carried out in different types of solvents which are used for further study. Saturated solutions were prepared by adding an excess drug to the vehicles and shaking on the shaker (REMI 
DGS-2) for $48 \mathrm{~h}$ at $25 \pm 0.5{ }^{\circ} \mathrm{C}$ under constant vibration. After this period the solutions were filtered, diluted and analyzed by UV spectrophotometer. Three determinations were carried out for each sample to calculate the solubility of the drug. The results are shown in Table 7.

Fourier Transform Infrared Spectroscopy of Drug: The infrared spectra of the pure drug were recorded by Shimadzu FT-IR spectrometer. Samples were prepared by $\mathrm{KBr}$ disc method (2 mg sample in $100 \mathrm{mg} \mathrm{KBr}$ ) and examined in the transmission mode. Each spectrum was measured over a frequency range of $4000-400 \mathrm{~cm}^{-1}$. The results are shown in Table 8 and Fig. 8.

Differential Scanning Calorimetry (DSC) Study of Drug: DSC analysis was performed using Shimadzu-Thermal Analyzer DSC 60 on 2-5 mg samples. The sample was heated in an open nitrogen pan at a rate of $10{ }^{\circ} \mathrm{C} / \mathrm{min}$ conducted over a temperature range of 30 to $230{ }^{\circ} \mathrm{C}$ for Piroxicam under a nitrogen flow of 2 bar pressure.
Thermogram, as shown in Fig. 9 and inference, showed in Table 9.

Partition Coefficient (Kp): ${ }^{16}$ The partition coefficient of the drug was determined by shaking equal volumes of oil and the aqueous phase in a separating funnel. A drug solution of $1 \mathrm{mg} / \mathrm{ml}$ was prepared in distilled water, and $50 \mathrm{ml}$ of this solution was taken in a separating funnel and shaken with an equal volume of octanol for $10 \mathrm{~min}$ and allowed to stand for $24 \mathrm{~h}$ with intermittent shaking. Then, the aqueous phase was assayed before and after partitioning using a UV spectrophotometer to get the partition coefficient values which is shown in Table $\mathbf{1 0}$.

\section{RESULT AND DISCUSSION:}

Organoleptic Properties: The Sample of drug received was studied for its organoleptic characters such as color, odor, and appearance as it is one of the first criteria for identification of compound and it shows results/properties which comply with reported literature standards. The result is presented in the following Table 1.

TABLE 1: COMPARISON OF THE RESULT OF ORGANOLEPTIC CHARACTERS OF DRUG SAMPLE WITH THE REPORTED STANDARDS

\begin{tabular}{cccc}
\hline S. no. & Identification Test & Observed Result & Reported Standard ${ }^{17,18}$ \\
\hline 1 & Appearance & Powder & Off-white to light tan or light yellow powder \\
2 & Colour & White & White / Off-white \\
3 & Odor & Odorless & Odorless \\
\hline
\end{tabular}

It is complying with the description that is found in the literature.

Melting Point: According to Indian Pharmacopoeia melting range/temperature of a substance is defined as those points of temperature within which / the point at which the substance begins to coalesce and is completely melted except as defined otherwise for certain substances ${ }^{68}$. The melting point of the drug complies with the reported literature values. The melting point of the drug was observed to be in the range of $197{ }^{\circ} \mathrm{C}$ $199{ }^{\circ} \mathrm{C}$ with decomposition, i.e. the substance characterize as it starts to melt which is shown in Table 2.

TABLE 2: COMPARISON OF THE RESULT OF THE MELTING POINT OF DRUG SAMPLE WITH THE REPORTED STANDARDS

\begin{tabular}{cccc}
\hline S. no. & $\begin{array}{c}\text { Identification } \\
\text { Test }\end{array}$ & $\begin{array}{c}\text { Observed } \\
\text { Result }\end{array}$ & $\begin{array}{c}\text { Reported } \\
\text { Standard }^{17}\end{array}$ \\
\hline 1 & Melting Point & $197^{\circ} \mathrm{C}-199^{\circ} \mathrm{C}$ & $198^{\circ} \mathrm{C}-200^{\circ} \mathrm{C}$ \\
\hline
\end{tabular}

\section{Ultraviolet Spectroscopy:}

Determination of Maximum Wavelength $\left(\lambda_{\max }\right)$ : Maximum wavelength $\left(\lambda_{\max }\right)$ is specific for every drug substances, and it is also one of the identification criteria. The maximum absorbance is for drug taken in methanol, methanolic $\mathrm{HCl}$ and phosphate buffer ( $\mathrm{pH}$ - 7.4). Observed peak and reported standard peak are shown in Table 3.

TABLE 3: MAXIMUM WAVELENGTH $\left(\lambda_{\max }\right)$ OF THE DRUG IN METHANOLIC HCI, METHANOL AND PHOSPHATE BUFFER

\begin{tabular}{ccc}
\hline Solvent & \multicolumn{2}{c}{$\boldsymbol{\lambda}_{\max }(\mathbf{n m})$} \\
\cline { 2 - 3 } & $\begin{array}{c}\text { Observed } \\
\text { Peak }\end{array}$ & $\begin{array}{c}\text { Reported } \\
\text { standard }^{\mathbf{1 9}}\end{array}$ \\
\hline Methanol & 333 & 333 \\
Methanolic HCl & 334.5 & 334 \\
Phosphate buffer & 354 & 354 \\
(pH 7.4 ) & & \\
\hline
\end{tabular}

$\lambda_{\max }$ for the drug in methanol, methanolic $\mathrm{HCl}$, and phosphate buffer (pH-7.4) was found, and it is shown in Fig. 2, Fig. 3, and Fig. 4 respectively. 
Spectra for the drug in methanol observed in the range of $200 \mathrm{~nm}$ to $400 \mathrm{~nm}$ which it shows absorption maxima at about $227 \mathrm{~nm}$ and $334.5 \mathrm{~nm}$ and minimum at about $242 \mathrm{~nm}$ which is shown in Fig. 2.

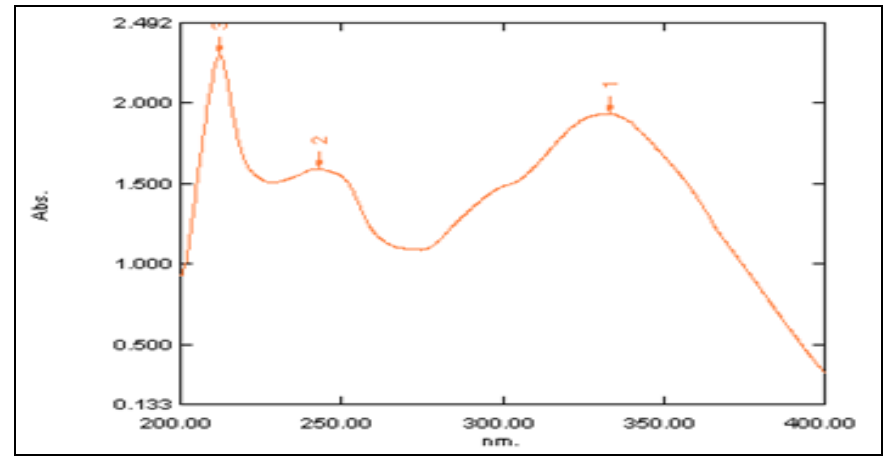

FIG. 2: $\lambda_{\max }$ FOR THE DRUG IN METHANOL

Spectra for the drug in methanolic $\mathrm{HCl}$ observed in the range of $220 \mathrm{~nm}$ to $400 \mathrm{~nm}$ for $0.0007 \% \mathrm{w} / \mathrm{v}$ solution of $0.01 \mathrm{M}$ methanolic $\mathrm{HCl}$ - absorption maxima at about $242 \mathrm{~nm}$ and $334 \mathrm{~nm}$ and minimum at about $270 \mathrm{~nm}$ which is shown in Fig. 3.

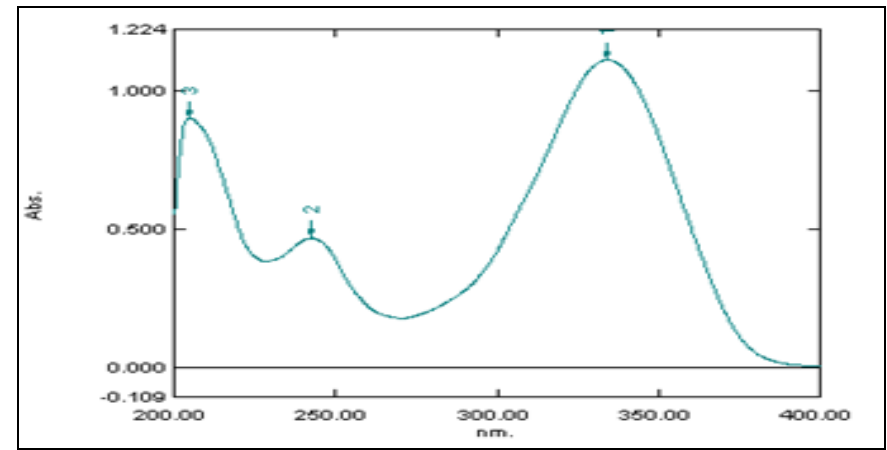

FIG. 3: $\lambda_{\max }$ FOR THE DRUG IN METHANOLIC HCI

Spectra for the drug in phosphate buffer ( $\mathrm{pH}-7.4)$ observed in the range of $200 \mathrm{~nm}$ to $400 \mathrm{~nm}$ for phosphate buffer ( $\mathrm{pH}-7.4)$. This spectrum shows four peak absorption maxima at about $221 \mathrm{~nm}, 250$ $\mathrm{nm}$, and $354 \mathrm{~nm}$ and minimum at about $279 \mathrm{~nm}$ which is shown in Fig. 4.

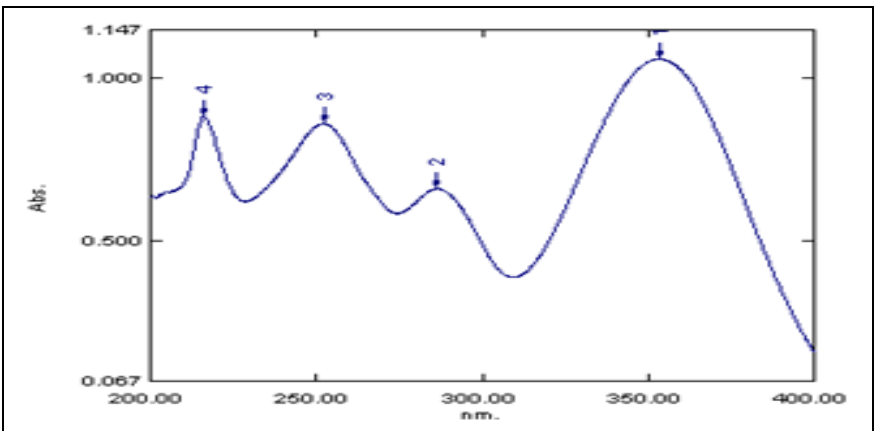

FIG. 4: $\lambda_{\max }$ FOR THE DRUG IN PHOSPHATE BUFFER (pH-7.4)

\section{Preparation of Beer Lambert's Plot:}

In Phosphate buffer (pH 7.4): Beer Lambert's plot of the drug was prepared in Phosphate buffer ( $\mathrm{pH} 7.4)$.

A linear relationship was obtained in between concentration $(2-10 \mu \mathrm{g} / \mathrm{ml})$, and the absorbance of the drug in phosphate buffer $(\mathrm{pH} 7.4)$ with an $\mathrm{R}^{2}$ value of 0.999 at $276 \mathrm{~nm}$ is shown in calibration curve shown in Fig. 5 and line equation, $y=0.072 x-$ 0.0038 .

TABLE 4: ABSORBANCE VALUE FOR DIFFERENT CONCENTRATIONS OF DRUG IN PHOSPHATE BUFFER (pH 7.4)

\begin{tabular}{ccc}
\hline S. no. & Concentration $(\boldsymbol{\mu g} / \mathbf{m l})$ & Absorbance $(\mathbf{n m})$ \\
\hline 1 & 0 & 0.000 \\
2 & 2 & 0.140 \\
3 & 4 & 0.287 \\
4 & 6 & 0.429 \\
5 & 8 & 0.574 \\
6 & 10 & 0.717 \\
\hline
\end{tabular}

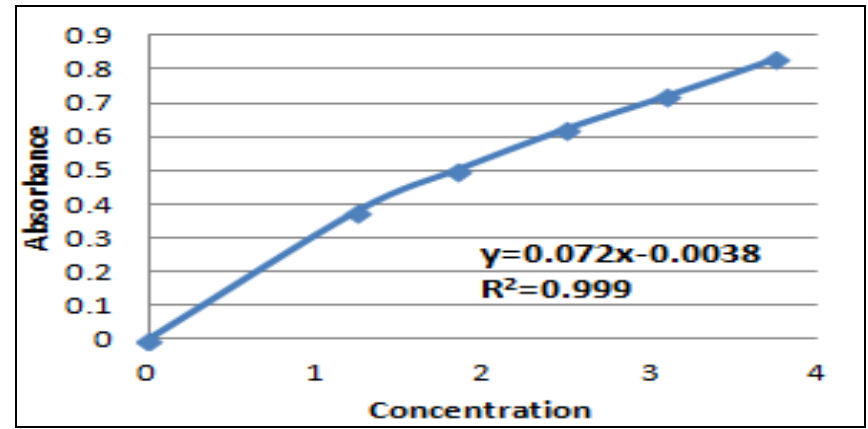

FIG. 5: BEER LAMBERT's PLOT OF THE DRUG IN PHOSPHATE BUFFER (pH 7.4)

In Methanolic HCl: Beer Lambert's plot of drug sample was prepared in methanolic $\mathrm{HCl}$. A linear relationship was obtained in between concentration $(1.25-3.75 \mu \mathrm{g} / \mathrm{ml})$ and the absorbance of the drug in methanolic $\mathrm{HCl}$ with an $\mathrm{R}^{2}$ value of 0.9979 at 276 $\mathrm{nm}$ is shown in calibration curve shown in Fig. 6 and line equation, $\mathrm{y}=0.1788 \mathrm{x}-0.1667$.

TABLE 5: ABSORBANCE VALUE FOR DIFFERENT CONCENTRATIONS OF DRUG IN METHANOLIC $\mathrm{HCl}$

\begin{tabular}{ccc}
\hline S. no. & Concentration $(\boldsymbol{\mu g} / \mathbf{m l})$ & Absorbance $(\mathbf{n m})$ \\
\hline 1 & 0.00 & 0.000 \\
2 & 1.25 & 0.381 \\
3 & 1.85 & 0.503 \\
4 & 2.5 & 0.624 \\
5 & 3.1 & 0.721 \\
6 & 3.75 & 0.831 \\
\hline
\end{tabular}




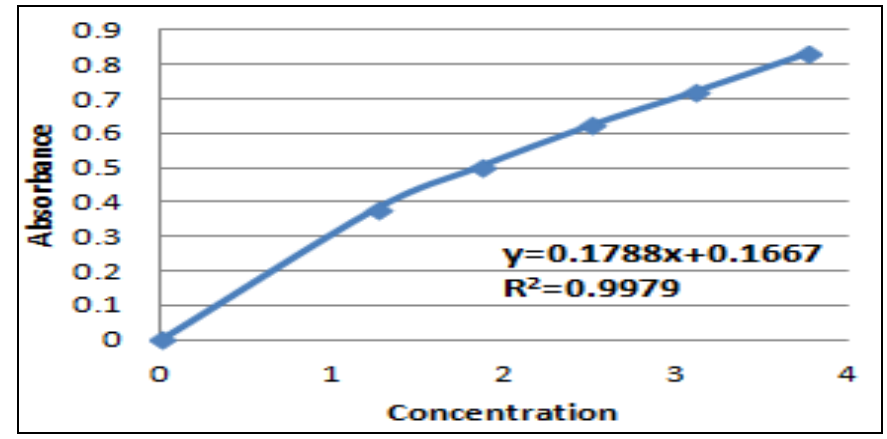

FIG. 6: BEER LAMBERT'S PLOT OF THE DRUG IN METHANOLIC HCl

In Methanol: Beer Lambert's plot of the drug was prepared in Methanol. A linear relationship was obtained in between concentration $(2-10 \mu \mathrm{g} / \mathrm{ml})$ and the absorbance of the drug in Methanol with an $\mathrm{R}^{2}$ value of 0.9999 at $276 \mathrm{~nm}$ is shown in calibration curve Fig. 7 line equation, $y=0.0728 x-$ 0.0005 .

TABLE 6: ABSORBANCE VALUE FOR DIFFERENT CONCENTRATIONS OF DRUG IN METHANOL

\begin{tabular}{ccc}
\hline S. no. & Concentration $(\boldsymbol{\mu g} / \mathbf{m l})$ & Absorbance $(\mathbf{n m})$ \\
\hline 1 & 0 & 0.000 \\
2 & 2 & 0.144 \\
3 & 4 & 0.296 \\
4 & 6 & 0.436 \\
5 & 8 & 0.582 \\
6 & 10 & 0.728 \\
\hline
\end{tabular}

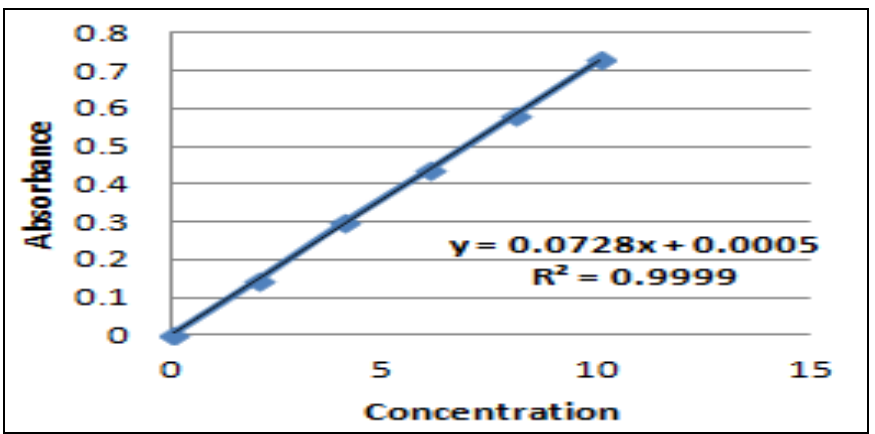

FIG. 7: BEER LAMBERT's PLOT OF THE DRUG IN METHANOL

Solubility Study of Drug: A test for solubility becomes a test for purity only where a special quantitative test is given in the individual monograph and is an official requirement. According to USP 2009, piroxicam is slightly soluble in ethanol and very slightly soluble in water, in dil. acids and most organic solvents ${ }^{21}$. Solubility study of drug sample was studied in different types of solvent and data shows that drug was very slightly soluble in water, soluble in phosphate buffer (pH-7.4) and freely soluble in rest of another solvent which is sown in Table 7.
TABLE 7: SOLUBILITY OF DRUG IN A DIFFERENT SOLVENT

\begin{tabular}{ccc}
\hline S. no. & Solvent & Solubility $(\mathbf{m g} / \mathbf{m l})$ \\
\hline 1 & Span 80 & 4.2 \\
2 & Lecithin & 2.6 \\
3 & Isopropyl myristate & 2.51 \\
4 & Propylene glycol & 7.1 \\
5 & Oleic acid & 5.20 \\
6 & DMSO & 5.8 \\
7 & PEG 400 & 2.663 \\
8 & Methanol & 5 \\
9 & Phosphate buffer (pH-7.4) & 0.592 \\
10 & Water & 0.0076 \\
\hline
\end{tabular}

Fourier Transform Infrared Spectroscopy of Drug: As we know, the infrared spectroscopy mostly used for the identification of organic compound whose spectra are complex and provides numerous maxima and minima that are useful for comparison purpose. Infrared spectroscopy finds widespread application to qualitative and quantitative analysis as no two compounds (except optical isomers) give similar absorption spectra in the IR region. The powdered mixture of drug sample and $\mathrm{KBr}$ was taken in a sampler, and the spectrum was recorded by scanning in the wavelength region of $4000-400^{-1} \mathrm{~cm}$ using FTIR spectrophotometer.

The FTIR spectra of piroxicam were taken which is shown in Fig. 8. The principal peak for IR of drug sample matched with the standard spectrum for Piroxicam which is shown in Table 8.

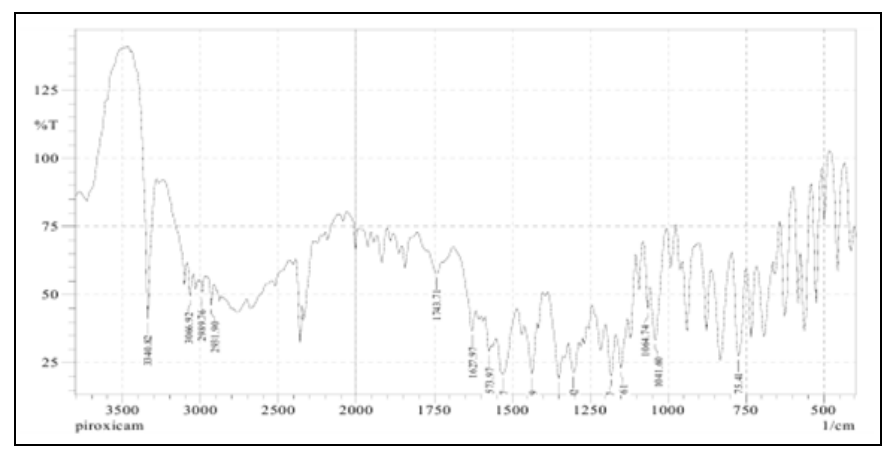

FIG. 8: IR SPECTRA OF DRUG

TABLE 8: INTERPRETATION OF IR OF DRUG

\begin{tabular}{cccc}
\hline $\begin{array}{c}\text { Characteristic } \\
\text { functional group }\end{array}$ & $\begin{array}{c}\text { Standard } \\
\text { range } \\
\left(\mathbf{c m}^{-\mathbf{1}} \mathbf{2 1}^{\mathbf{2 1}}\right.\end{array}$ & $\begin{array}{c}\text { Reference } \\
\text { Peaks } \\
\left(\mathbf{c m}^{-\mathbf{1}} \mathbf{2 n}^{\mathbf{2}}\right.\end{array}$ & $\begin{array}{c}\text { Observed } \\
\text { peak } \\
\left(\mathbf{c m}^{-\mathbf{1}}\right)\end{array}$ \\
\hline$-\mathrm{OH}$ and -NH streaching & $3650-3300$ & $3338 \mathrm{~cm}^{-1}$ & 3340.82 \\
Aromatic -C=C-H & $3300-2700$ & 3065 & 3066.92 \\
$\mathrm{C}=\mathrm{O}$ streaching & $1850-1680$ & 1630 & 1743.71 \\
Aromatic -C=C- & $1680-1450$ & 1574 & 1627.97 \\
Ar-NH & $1360-1250$ & 1351 & 1350.22 \\
$\mathrm{~N}_{-} \mathrm{CH}_{3}$ streaching & $1220-1050$ & 1150 & 1180.47 \\
$-\mathrm{SO}_{2}-\mathrm{N}=$ Group & $1070-1050$ & 1065.2 & 1064.74 \\
o-disubstituted phenyl & 750 & 775 & 775.41 \\
\hline
\end{tabular}


Differential Scanning Calorimetry (D.S.C.) Study of Drug: The endotherm of melting corresponds to the portion of the DSC curve that is far from the baseline and later returns to it. Melting is a physical process that results in the phase transition of a substance from solid to liquid. This occurs when the internal energy of the solid increase, typically by the application of heat which increases the substance's temperature to the melting point. In DSC, as the temperature increases, the sample eventually reaches its melting temperature $(\mathrm{Tm})$. The melting process results in an endothermic peak in the DSC curve.

DSC studies were performed for drug sample. The DSC thermogram of commercial drug sample is presented in Fig. 9 and interpretation is shown in Table 9. Thermogram of DSC of the drug shows melting in the range between 203.45 to $206.11^{\circ} \mathrm{C}$, and the sharp peak was seen at $201.20^{\circ} \mathrm{C}$. So, it shows that it is an endothermic reaction. The following figure shows the endothermic peak of the drug with height $-25.76 \mathrm{~mW}$.

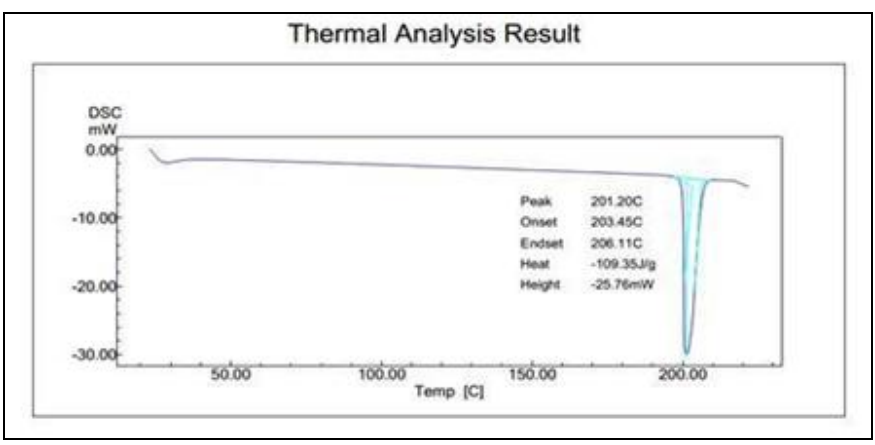

FIG. 9: DSC THERMOGRAM OF DRUG

TABLE 9: INTERPRETATION OF DSC OF DRUG

\begin{tabular}{ccc}
\hline $\begin{array}{c}\text { Name of } \\
\text { Substance }\end{array}$ & $\begin{array}{c}\text { Melting } \\
\text { Point }\end{array}$ & Inference \\
\hline Piroxicam & $201.20^{\circ} \mathrm{C}$ & $\begin{array}{c}\text { Sharp endothermic peak } \\
\text { obtained and it matches } \\
\text { with official standard. }\end{array}$ \\
\hline
\end{tabular}

Partition Coefficient (Kp): The permeability coefficient was found to be 3.09 which indicate that drug sample is lipophilic and come under high (value 3-4) class and results were shown in Table 10. It is worth noting that this is a $\log P=0$ means that the compound is equally soluble in water and the partitioning solvent. If the compound has a log $P=5$, then the compound is 100,000 times more soluble in the partitioning solvent. A $\log P=-2$ means that the compound is 100 times more soluble in water, i.e. it is quite hydrophilic (Kohler et al.,
1988). Therefore, from obtained result drug have 1000 times more soluble in the partitioning solvent (octanol).

TABLE 10: COMPARISON OF THE RESULT OF PARTITION COEFFICIENT (Kp) DRUG SAMPLE WITH THE REPORTED STANDARDS

\begin{tabular}{ccc}
\hline S. no. & Observed value & Reported standard \\
\hline 1 & 3.09 & 3.06 \\
\hline
\end{tabular}

CONCLUSION: In the present work, the preformulation study of piroxicam drug was done. Preformulation studies have a significant part to play in anticipating formulation problems and identifying a logical path in both liquid and solid dosage form technology. This study shows a satisfactory result for all characterization such as organoleptic properties, calibration curve, DSC, partition coefficient, etc. All results matched with the reported standard.

ACKNOWLEDGEMENT: The author thankful to Dr. Anil G. Jadhav and Mr. Satish A. Ahire for their valuable guidance.

CONFLICT OF INTEREST: We declare that we have no conflict of interest.

\section{REFERENCES:}

1. Chaurasta G: A review on pharmaceutical preformulation studies in formulation and development of new drug molecules. International Journal of Pharmaceutical Science and Research 2016; 7(6): 2313-2320.

2. Sadeq OR: Piroxicam- induced hepatotoxicity. Biomedical Journal of Scientific \& Technical Research 2018; 2(3): 16.

3. Panzade P, Shendarkar G, Shaikh $\mathrm{S}$ and Rathi PB: Pharmaceutical Cocrystal of Piroxicam: Design, Formulation and Evaluation 2017; 7(3): 399-408.

4. Bhargav E, Surya C, Reddy P, Sowmya C, Haranath C, Khan KAA, Rajesh K and Srinath B: Formulation, and optimization of Piroxicam orodispersible tablets by central composite design. Journal of Young Pharmacists 2017; 9(2): 187-191.

5. Bachhav AA, Jadhav AG, Pawar AY and Ahire SA: Development of proniosomal drug delivery with a different type of penetration enhancers. International Journal of PharmTech Research 2018; 11(01): 57-73.

6. Moghimipour E, Dabbagh $\mathrm{MA}$ and Zarif F: Characterization and in-vitro evaluation of Piroxicam suppositories. Asian Journal of Pharmaceutical and Clinical Research 2009; 2I(3).

7. Shaji $\mathbf{J}$ and Lal M: Novel double loaded transforosomes: evidence of superior anti-inflammatory efficacy- a comparative study, International Journal of Current Pharmaceutical Research 2014; 6(2): 16-25.

8. Trivedi HJ, Thakur RS, Ray S and Patel KR: Design and evaluation of Piroxicam microemulsion, International Journal of Pharmaceutical Research Scholars 2012; 1(2): 166-177. 
9. Panzade P, Shendarkar G, Shaikh S and Rathi PB: Pharmaceutical Cocrystal of Piroxicam: Design, Formulation and Evaluation 2017; 7(3): 399-408.

10. Barani S, Ali $M$ and Amin S: Formulation, and characterization of flexible phosphatidylcholine vesicles for systemic delivery of Piroxicam. Journal of Pharmaceutical Science \& Research 2017; 9(6): 972-985.

11. Garg V, Singh H, Bhatia A, Raza K, Singh SK, Singh B and Beg S: Systematic development of transethosomal gel system of Piroxicam: formulation optimization, in-vitro evaluation, and ex-vivo assessment. American Association of Pharmaceutical Scientists 2016; 18(1): 58-71.

12. Garg V, Singh H and Singh SK: Development and validation of a sensitive UV method for piroxicam: application for skin permeation studies. International Journal of Recent Scientific Research 2014; 5(5): 980-983.

13. Dhage MA, Chhabra GS and Banerjee SK: Development and validation of UV spectrophotometric method for piroxicam in bulk and pharmaceutical formulation .J. Chem Pharm Res 2011; 3(2): 765-769.

14. Garg V, Singh H and Singh SK: Development and validation of a sensitive UV method for piroxicam: application for skin permeation studies. International Journal of Recent Scientific Research 2014; 5(5): 980-983.

15. Ahmed S, Abdul $\mathrm{J}$ and Ahmed $\mathrm{H}$ : Formulation and evaluation of piroxicam liquisolid compacts. International
Journal of Pharmacy and Pharmaceutical Science 2008; 5: $132-141$

16. Jamakandi VG, Mulla JS, Vinay BL and Shivakumar HN: Formulation, characterization, and evaluation of matrixtype transdermal patches of a model antihypertensive drug, Asian journal of pharmaceutics 2009; 3: 59-65.

17. http://www.drugbank.ca/drugs/DB0055453

18. https://pubchem.ncbi.nlm.nih.gov/compound/urea\#section $=$ Dissociation-Constants

19. Qi L, Zhanrong L, Weidong Z, Shumin G, Haoyang L, Chuanbin W, Li G, Dan L and Yuehong X: Proniosomederived niosomes for tacrolimus topical ocular delivery: in-vitro cornea permeation, ocular irritation, and in-vivo anti-allograft rejection. European Journal of Pharmaceutical Sciences xxx 2014; 1-9.

20. Pavia DL, Lampman GM, Kriz GS and Vyvyan JR: Spectroscopy, Cengage Learning, India $4^{\text {th }} \operatorname{ed}^{\text {n }} .2012 ; 29$ 31.

21. The United States Pharmacopeia-National Formulary. The official compendia of standards. Asian Edu, USP 30, NF, 2007; 1: 845-890.

22. Jain N, Talegonkar S and Jain NK: New ways to enter the blood stream emerging strategies in transdermal drug delivery. The Pharma Review 2004; 41-60.

\section{How to cite this article:}

Bachhav AA, Ahire SA and Jadhav AG: Preformulation study of piroxicam. Int J Pharm Sci \& Res 2019; 10(2): 811-18. doi: 10.13040/ IJPSR.0975-8232.10(2).811-18.

All @ 2013 are reserved by International Journal of Pharmaceutical Sciences and Research. This Journal licensed under a Creative Commons Attribution-NonCommercial-ShareAlike 3.0 Unported License.

This article can be downloaded to ANDROID OS based mobile. Scan QR Code using Code/Bar Scanner from your mobile. (Scanners are available on Google Play store) 